\title{
HCAR1 wt Allele
}

National Cancer Institute

\section{Source}

National Cancer Institute. HCAR1 wt Allele. NCI Thesaurus. Code C150256.

Human HCAR1 wild-type allele is located in the vicinity of $12 \mathrm{q} 24.31$ and is approximately 5 $\mathrm{kb}$ in length. This allele, which encodes hydroxycarboxylic acid receptor 1 protein, is involved in lactate-mediated signaling. 